\title{
Law, Democracy and the Fulfilment of Socio-economic Rights: \\ Insights from Indonesia
}

by

\author{
Andrew Rosser \\ University of Adelaide \\ and \\ Maryke van Diermen \\ University of Adelaide
}

c/o School of Social Sciences, University of Adelaide, Adelaide SA 5005 Australia

Ph: +61 (8) 83034938

$\underline{\text { andrew.rosser@adelaide.edu.au }}$

maryke.vandiermen@adelaide.edu.au

Corresponding Author: Andrew Rosser

\section{Acknowledgements}

Research for this paper was supported by the Australian Research Council through grant number FT110100078

\section{Biographies}

Andrew Rosser is Associate Professor of Development Studies at the University of Adelaide Maryke van Diermen is a PhD student in Development Studies at the University of Adelaide 


\begin{abstract}
In recent years, a debate has emerged about the conditions under which justiciable legal frameworks facilitate the fulfilment of socio-economic rights. This debate has pit institutionalist perspectives that emphasise the progressive potential of democratisation against structuralist perspectives that emphasise the constraints imposed by relationships of power and interest. This paper considers this debate in light of Indonesia's recent experience. It suggests that we need to examine how institutional and structural factors interact within particular contexts to shape socio-economic rights fulfilment, not examine these factors in isolation. It also considers the strategic implications of this argument for rights proponents.
\end{abstract}

Keywords: law, human rights, Indonesia, democratisation, structuralist, institutionalist 


\section{Introduction}

The Universal Declaration of Human Rights (UDHR), formulated in 1948, provides for six socioeconomic rights in addition to numerous civil and political rights. These are: the right to food, the right to health, the right to education, the right to housing, the right to work, and the right to social security. ${ }^{1}$ Recent decades have seen an increased number of developing countries make a potentially enforceable legal commitment to these rights by ratifying the International Covenant on Economic, Social and Cultural Rights (ICESCR), ratifying other pieces of international law that provide for socio-economic rights such the Convention on the Elimination of All Forms of Discrimination Against Women (CEDAW) and the Convention on the Rights of the Child (CRC), and/or enshrining socio-economic rights in national constitutions and law. For instance, Gauri found that of 165 countries with written constitutions, 116 referred to a right to education and 73 a right to health care. ${ }^{2}$ The fulfilment of socio-economic rights has also become an increasingly important objective for international development organisations, in particular United Nations agencies and NGOs that are formally committed to rights-based approaches to development. ${ }^{3}$

Despite this trend, however, developing countries' progress in fulfilling socio-economic rights has been slow and uneven. According to Fukuda-Parr et al, ${ }^{4}$ developing countries' average score on the Social and Economic Rights Fulfilment (SERF) Index ${ }^{5}$ increased by only 10 points between 1985 and 2005 to reach a point where they were achieving roughly 70 percent of what is possible. At the same time, their scores in relation to specific rights indicate that they did much better in realising some rights than others. At the aggregate level, the most substantial gains between 1975 and 2005 were in relation to the right to education; more modest gains were made in relation to the rights to health, food and housing; and no gains were made in relation to the right to work. There has also been substantial variation at the individual country level. For instance, while Vietnam has achieved a middling score on the SERF Index in terms of overall fulfilment of socioeconomic rights, it has one of the highest scores in relation to fulfilment of the right to health. 
Likewise, Nigeria scores poorly on the aggregate measure but has a reasonable score in relation to the right to education. ${ }^{6}$

What explains developing countries' slow and uneven progress in promoting the fulfilment of socio-economic rights? Much commentary on human rights in developing countries, particularly that emanating from international human rights NGOs such as Amnesty International and Human Rights Watch and other proponents of rights-based approaches to development, has suggested that the problem lies primarily in inadequate protection for human rights in countries' legal frameworks. Viewing the law as a powerful force for change, ${ }^{7}$ these organisations have focused on identifying legislative and policy gaps that need to be filled to ensure better protection of rights. ${ }^{8}$ But with more and more developing countries signing up to international human rights treaties and/or incorporating socio-economic rights into national constitutions and law, these countries' legal frameworks for the protection of human rights are increasingly becoming consistent with international norms. At the same time, many scholars have shown that justiciable legal frameworks for the protection of human rights (JLFPHR) are not self-activating - that is, they do not lead automatically to the realisation of rights in practice; they only do so when certain political and social prerequisites are in place. ${ }^{9}$ This implies that the most important determinants of socioeconomic rights outcomes in developing countries lie in the political and social realm rather than the legal realm.

In this context, a debate has emerged about the political and social conditions under which JLFPHR facilitate the fulfilment of socio-economic rights. Broadly, this debate has pit institutionalist perspectives that emphasise the role of political regimes and judicial institutions in shaping the scope for rights fulfilment against structuralist perspectives that focus on the constraints imposed by relationships of power and interest. Whereas the former suggest that democratisation has progressive potential because it increases citizens' ability to engage in political and legal mobilisation and changes elite incentives, ${ }^{10}$ the latter suggest that such changes matter little in a 
context of unequal relationships of power between competing social interests and elite capture of political and legal institutions. ${ }^{11}$

This paper considers these perspectives in light of Indonesia's experience since the fall of the authoritarian 'New Order' regime in 1998-1999. This period in Indonesia's history provides a useful context for assessing these perspectives because it combines democratization, improved legal protection for socio-economic rights, and differentiated social rights outcomes. The collapse of the New Order ushered in a transition to democratic rule that has proven durable notwithstanding some recent backtracking on reform. At the same time, Indonesian legislation was extensively revised following the fall of the New Order to provide citizens with the full range of socio-economic rights enunciated in the UDHR. But the country has subsequently made only moderate progress in fulfilling these rights while making much more progress in realising the rights to education and health than the rights to employment and social security. This experience begs the question: Why, given the presumed benefits of JLFPHR and democracy for socio-economic rights fulfillment, has Indonesia's progress in fulfilling such rights been so limited and uneven?

We argue that this outcome reflects the way in which democratization has interacted with constraints imposed by the structural context. Democratization removed obstacles to mobilization by citizens and rights activists for better protection of socio-economic rights, gave them greater access to policy-making processes, and created an electoral incentive for political leaders to introduce social protection programmes aimed at helping the poor fulfill these rights. But the continued political dominance of a coalition that has selective interests vis-à-vis the fulfilment of socio-economic rights has shaped the way in which their agendas/demands have been accommodated in government policy and its implementation. Specifically, it has ensured that government investments in new social protection programmes were limited in generosity, focused on areas that contribute to economic growth, and subject to capture by predatory networks - in so doing, the limiting both the overall extent and pattern of rights fulfilment. 
In terms of the above debate, then, our analysis suggests that we need to consider how institutional and structural factors interact within particular contexts, not just focus on one or the other. Democratisation can, as institutionalists suggest, contribute to socio-economic rights realisation by facilitating increased political and legal mobilisation by citizens around issues of socio-economic rights and shifting elite incentives in a pro-poor direction. But its precise effects are mediated by the broader structures of power and interest in which this occurs. Specifically, these structures shape the priorities that democratic regimes give both to socio-economic rights fulfilment in general and the fulfilment of specific rights in particular. In policy terms, our analysis thus supports recommendations for institutional reforms that enable citizens to engage in legal and political mobilization and open up spaces giving them access to state decision making processes. But it adds an important caveat: namely, that, given rights advocates' significant resource and time constraints, efforts to promote mobilization and access ought to focus on contexts where structural factors make the chances of success relatively high.

In presenting this argument, we begin by summarising in greater detail the institutionalist and structuralist perspectives mentioned above. We then provide an analysis of Indonesia's experience vis-à-vis the fulfilment of socio-economic rights and the way in which this has been shaped by both institutional factors (in particular democratization) and structural factors (in particular, continued rule by a coalition of interests with selective interests in socio-economic rights fulfilment). The final section of the paper examines the implications of the analysis for efforts to promote socio-economic rights in developing countries.

\section{The Competing Perspectives}

Much of the existing literature on JLFPHR and the fulfilment of socio-economic rights in developing countries has emerged from within the institutionalist tradition in comparative political economy. ${ }^{12}$ While this tradition is very diverse, it is centrally concerned with the way in which institutions - often defined following North as 'the rules of the game' — influence who has access to 
the policy-making process, on what terms, and to what effect. ${ }^{13}$ Accordingly institutionalist work on JLFPHR and the fulfilment of socio-economic rights in developing countries has suggested that the prospects for rights fulfilment hinges primarily on the way in which political and legal institutions shape who has access to rights-related policy-making (including court) processes, citizens' ability to mobilise for political and legal action in relation to rights issues, and the responsiveness of political elites and judges to these issues.

Broadly speaking, scholars working in this tradition have produced two lines of enquiry. The first has focused on the effects of different political regimes and has suggested that democracy is more conducive to the fulfilment of socio-economic rights than authoritarianism. Fukuda-Parr et $a l$, for instance, have shown that the more democratic a developing country, the less likely it is to have a low score on the SERF Index. ${ }^{14}$ In other words, they argue, democracy places a 'floor' on social and economic rights achievement. ${ }^{15}$ Similarly, Joshi and Moore have argued that legally enforceable socio-economic rights will facilitate political mobilisation by the poor when they are part of a broader 'enabling institutional environment' for such mobilisation characterised by tolerance, credibility, and predictability as well as rights. ${ }^{16}$ While they do not explicitly say so, this environment is most likely to exist in stable democracies. But by far the most influential work in this vein has been Simmons' analysis of the impact of ratification of international human rights treaties. ${ }^{17}$ According to Simmons, the ratification of international human rights treaties has had a greater positive impact on the fulfilment of human rights - including socio-economic rights—in countries with institutionally unstable political regimes than in those with stable political regimes. ${ }^{18}$ In stable autocracies, she notes, citizens have the motive to mobilise in relation to human rights issues but, facing authoritarian controls, do have not the means while in stable democracies 'they have the means but generally lack a motive'. ${ }^{19}$ In countries with unstable political institutionstypically ones undergoing transition from authoritarian to democratic rule-citizens have both the motive and the means. In her analysis, it is assumed that citizen mobilisation around rights issues 
will yield receptive responses from political elites in accordance with the extent of that mobilization and their ability to access policy-making spaces.

The second line of enquiry has focused on the role of courts in promoting the fulfilment of social rights particularly in democracies. Drawing on Epp's work on 'rights revolutions', ${ }^{20}$ a number of scholars, for instance, have pointed to the importance of 'support structures for legal mobilisation' (SSLMs) in enabling citizens in developing countries to promote socio-economic rights through the judicial system. ${ }^{21}$ JLFPHR, it is argued, can only be enforced when potential litigants are able to mobilize the financial and technical resources required to access and utilise the court system by, for instance, accessing state-provided legal aid or securing the support of activist lawyers willing to work pro bono (their resources constituting the SSLM). Against this, other scholars have argued that the realisation of socio-economic rights is shaped primarily by the institutional design of courts and in particular the way in which this affects (i) citizens' access to courts and (ii) the incentives that judges face in issuing their judgments. Wilson, for instance, has argued that 'rights revolutions' in Costa Rica and Columbia over the past two decades stemmed from the fact that Superior Courts in these countries abandoned high levels of judicial formality, adopted of broad definitions of standing, removed barriers to access, and resolved cases quickly, thereby making it possible for poor and marginalised groups to access and utilise the court system notwithstanding the absence of a strong SSLM. ${ }^{22}$ Similarly, Ginsburg has argued that factors such as judges' remuneration and appointment processes and the extent of judiciaries' independence from the executive have heavily influenced the responsiveness of Asian Constitutional Courts to citizen demands related to human rights. $^{23}$

An alternative set of perspectives has emerged out of the structuralist tradition in political science. In broad terms, this tradition has interpreted political, economic and social outcomes in terms of historically-specific contests between competing coalitions of interest (especially classbased coalitions), the relationships of power between them, and the way in which these shape state action. ${ }^{24}$ In relation to the effect of law on the realization of socio-economic rights, this tradition has 
yielded a view that emphasises the obstacles to rights realisation presented by the political dominance of capitalist, predatory and neoliberal elites who are materially disadvantaged by or ideologically opposed to stronger protection of socio-economic rights regardless of the nature of countries' political regimes. Such analyses have recognized that courts matter as an arena of contestation over socio-economic rights but they have not given them privileged attention. Rather they have placed predominant emphasis on the way in which structures of power and interest have constrained state action/inaction vis-a-vis the realization of socio-economic rights whether this has been via the formulation of policy, its implementation in practice, or law enforcement through the courts. In many respects, such analyses are similar to work in the 'law and social movements' tradition which focused on the US. This work questioned the point of rights activists trying to operate through US courts because of the latter's perceived conservative bias but noted the potential for them to do so through political mobilization and engagement with the political system. ${ }^{25}$ Structuralist perspectives differ in their more systematic consideration of the social foundations of the state and the way in which this constrains state action across the board - that is, not just via the courts but also via political institutions and the bureaucracy-even in the context of democratic political systems.

Cousins' analysis of struggles over land reform in rural South Africa constitutes one example of such structuralist analysis. ${ }^{26}$ In capitalist systems, he argues, the tension between the interests of capital and labour and the political dominance of the former mean that legal rights to property are typically given precedence over the rights of labour when the two are in conflict. In South Africa, this has been reflected in the continued forced evictions of labourers and dwellers despite the introduction of tenure security laws. Baxi's analysis of 'social action litigation' (SAL) in India during the late 1970 s and early 1980 s also has strong structuralist dimensions. ${ }^{27}$ According to Baxi, SAL was driven largely by the Indian judiciary as part of a populist strategy aimed, not simply at ameliorating the misery of the masses, but also restoring the image of the Court following the 1975-76 Emergency and establishing a new base of legitimacy for judicial authority. At the 
same time, however, he notes that it emerged within the context of a wider political and social struggle between India's poor and marginalised, on the one hand, and 'regressive forces,' on the other. While Baxi places significant emphasis on the agency of the judiciary, he notes that ultimately this amounted to little. The modest changes produced by SAL, he says, made it 'at best an "establishment revolution", indicating the constraints to rights fulfilment imposed by the broader structure of power and interest. ${ }^{28}$

Although less explicitly class-centric, Grugel and Piper's work on global governance and human rights also broadly falls into this camp. ${ }^{29}$ States in developing countries, they suggest, are generally controlled by groups that are unsympathetic to rights-related causes, making the development of rights-friendly policies and their implementation and enforcement difficult, whatever the formal legal framework. At the same time, the possibilities for change are greater in relation to civil and political rights than socio-economic rights because the former accord more closely with the 'contemporary liberal agenda of global politics' ${ }^{30}$ In a more recent piece, Grugel and Peruzzotti have pointed to the way in which differences in the domestic politics of democratic states in the developing world can produce different outcomes at the national level with regards to compliance with international human rights treaties in the wake of ratification, noting that in some cases they can be conducive to rights fulfilment. ${ }^{31}$ And Piper has argued that marginalized groups can promote rights fulfillment by engaging in collective action aimed at claiming rights provided for in law. ${ }^{32}$ But, in general, the emphasis in structuralist accounts has been on the constraints that domestic and international political structures present to rights fulfilment.

In the following section, we test the ideas associated with these two broad perspectives against Indonesia's experience vis-à-vis the fulfilment of socio-economic rights since the fall of the New Order. In so doing, we begin by providing an overview of socio-economic rights in Indonesian law and the country's performance in realizing these rights in practice. We then examine the politics underlying this performance focusing on the effects of democratization, on the one hand, and structural factors, on the other. 


\section{The Indonesian Case}

\section{Socio-economic Rights in Law and Practice in Indonesia}

During the 'New Order' period (1965-1998), Indonesian legislation provided Indonesian citizens with few socio-economic rights. The original version of the 1945 Constitution, which was in force during this period, provided citizens with the right to work and 'a way of living that is appropriate for humanity' (Article 27 (2)). It further provided citizens with a right to 'instruction' (pengadjaran) (Article 31 (1)) but made no provision for this to be provided free at the elementary level, in contrast to commitments regarding education in the UDHR and ICESCR. It is unclear whether this right to instruction amounted to a right to education given that subsequent legislation (namely, Law 2/1989 on a National Education System) defined 'instruction' as merely one component of 'education' ${ }^{33}$ At the same time, the original version of the 1945 Constitution made no provision for rights to health services, social security, food or water. Law 7/1996 on Food noted in its preliminary sections that 'fulfilment of the basic human need for food is the human right of all Indonesians in creating quality human resources to implement national development'. But it did not explicitly provide Indonesian citizens with a right to food nor explain any limitations on this right implied by the caveat regarding 'quality human resources' and the implementation of national development.

Since the fall of the New Order, Indonesian legislation has been extensively revised to provide for a much greater range of socio-economic rights. The 1945 Constitution was amended between 1998 and 2002 to include a bill of rights that broadly mirrors the UDHR. ${ }^{34}$ This change means that, in addition to maintaining citizens' rights to work and an appropriate standard of living, it now provides for rights 'to obtain an education' (Articles $28 \mathrm{C}$ and 31 (1)), 'to obtain health services' (Article 28H (1)), to have access to social security (Article 28H (3)), and to 'develop oneself through the fulfilment of basic needs' (Article 28C (1)). The amendments also included a 
new provision requiring the government to fund compulsory basic education (Article 31 (2)), effectively creating a new legal right to free basic education. To this end, another amendment introduced a requirement for Indonesian governments at all levels (national, provincial and district) to spend at least 20 percent of their respective budgets on education.

At the same time, the national parliament has enacted a number of subordinate laws that have reaffirmed and, in some cases, expanded upon these rights. The earliest post-New Order piece of legislation on human rights, Law 39/1999 on Human Rights (enacted before the aforementioned Constitutional changes), provides for the protection of rights to education, work, social security and health services, although in the latter case only for children. Several subsequent laws-most notably Law 23/2002 on Child Protection, Law 20/2003 on a National Education System, Law 40/2004 on a National Social Security System, Law 11/2005 on the Ratification of the International Covenant on Economic, Social and Cultural Rights (ICESCR), and Law 36/2009 on Health—also provide (between them) for protection of the rights to education, work, social security, and health services. Law 7/2004 on Water Resources recognizes that Indonesians have a right to 'obtain water for their minimal daily needs' (Article 5) and requires the state to ensure that this is fulfilled. Law 18/2012 on Food provides a similar guarantee for the right to food as that provided by Law 7/1996 but it goes slightly further, stating that fulfilment of citizens' right to food is 'guaranteed' by the amended 1945 Constitution.

This enhanced legislative protection for socio-economic rights in Indonesia has not, however, translated to the broad fulfilment of these rights in practice, although it has been accompanied by some improvement. Indonesia's score on the Social and Economic Rights Fulfilment (SERF) Index rose from 55.66 in 1995 to 65.71 in 2012. At this level, it remains well short of the level commensurate with rights fulfilment. ${ }^{35}$ This score placed it firmly in the bottom half of the 103 developing and transition countries ranked in the SERF Index. ${ }^{36}$ At the same time, as the SERF component indices show, Indonesia's achievements have been highly uneven across type of socio-economic right (Table One). The country has made significant progress in realizing the 
rights to education and health but rather less progress in realizing the rights to food, work, and housing (the latter being defined in terms of citizens' access to clean water and sanitation). ${ }^{37}$ The post-New Order period has seen a significant improvement in relation to the right to work as the economy has grown strongly in the wake of the Asian economic crisis but this broad pattern in favour of education and health rights has remained. The SERF project does not measure countries' progress vis-à-vis the right to social security because of a lack of reliable relevant data. ${ }^{38}$ But it is almost certain that the country's performance in fulfilling this right has also been poor given that the country has not developed a social safety net for the unemployed, underemployed, elderly, and disabled beyond central and regional government programs that provide free health insurance for the poor.

\section{INSERT TABLE ONE HERE}

\section{The Political Economy of Socio-economic Rights Fulfilment}

Underlying this outcome has been the way in which the progressive effects of democratization have intersected with constraining effects of continuities in the structure of power and interest over time. Democratization created greater scope for progress vis-à-vis the fulfilment of socio-economic rights in three ways. First, it created an incentive for politicians and their political parties to promote policies supporting fulfilment of socio-economic rights because of their utility in fostering a mass base of political support and, in turn, securing votes at election time. Examples of politicians who responded to this incentive included, at the regional level, the former bupatis of Bantul and Jembrana, Idham Samawi, and I Gede Winasa respectively, and, at the national level, former President Susilo Bambang Yudhoyono, and current President Joko Widodo. ${ }^{39}$ In all these cases, these figures promoted progressive social programs, typically targeted at the poor but in some cases universal in orientation, as key parts of their political strategies. Combined with policies aimed at increasing teachers' salaries (such as the national teacher certification program), ${ }^{40}$ such strategies 
have enabled politicians to build a political base within the country's education and health systems, both of which are institutionalized down to the village level, yielding potentially significant payoffs in electoral terms.

Second, democratization removed key obstacles to mobilization by the poor and NGOs both in general and in relation to issues of socio-economic rights in particular. For instance, the postNew Order period witnessed the establishment of a wide range of new NGO and citizens groups with a dedicated focus on social policy issues and strong commitment to socio-economic rightse.g. the Ecosoc Institute, People's Coalition for the Right to Water (KRuHA), the Indonesian Poor People's League (SRMI), the People's Health Council (DKR), and parents groups-or an agenda broad enough to incorporate a concern with such issues and rights-e.g. Indonesia Corruption Watch (ICW), the Indonesian Forum for the Environment (WALHI), and the Trade Union Rights Center (TURC). At the same time, some human rights and other NGOs that were established during the New Order — most notably the Jakarta Legal Aid Institute (LBH Jakarta), the Institute for Policy Research and Advocacy (ELSAM), the Indonesian Consumers' Foundation (YLKI), and Yayasan Emong Lansia/HelpAge Indonesia—became increasingly active in relation to social policy issues. ${ }^{41}$ Their critique of the New Order's human rights record-including its record vis-à-vis socioeconomic rights ${ }^{42}$ - and the problems of legitimacy it generated were crucial in encouraging the country's political elite to revise the 1945 Constitution to incorporate stronger protection of socioeconomic rights in the period immediately following the fall of the New Order.

Finally, democratization opened up new policy spaces allowing NGOs and citizens groups to participate more substantially in the policy-making process than was possible under the New Order, again including specifically in relation to issues of socio-economic rights. The Indonesian parliament became more accessible as public consultations during legislative processes became commonplace, the media become an important forum for genuine public policy debate, and former civil society activists were able to penetrate the political parties, giving them an increased role in party rooms and parliamentary commissions. ${ }^{43}$ Finally, the court system became both more 
receptive to human rights-related causes as the judiciary sought to establish its reform credentials and more accessible, as the growing role of NGOs in socio-economic rights activism enhanced the scope for legal mobilisation. The Constitutional Court - a newly established court-became a particularly important institutional pathway for NGOs and citizens groups in this respect because of its relatively liberal and flexible rules concerning legal standing, affordable costs and more progressive orientation than other Indonesian courts.

Within this context, several NGOs and citizen groups successfully made use of the new socio-economic rights provided for in the revised Constitution and new laws to challenge government policies that threatened to undermine these rights via engagement with parliament and the court system. Key examples included their campaigns in relation to the 2004 Water Services law, 2008 Education Legal Entities Law, the government's 'international standard schools' policy, changes to the implementation of the country's 'national exam', and the planned privatization of 3 public hospitals in Jakarta in 2004-2005. ${ }^{44}$ In all cases, the relevant government policies were deemed by critics to infringe citizens' socio-economic rights by promoting privatization, corporatization or other elements of the neoliberal policy agenda. More pro-actively, between 2009 and 2011, NGOs joined with a large section of the trade union movement to organise large demonstrations and lodge a court case aimed at pressuring the government to implement the 2004 social security law by passing a new piece of legislation on Social Security Implementing Agencies (BPJS). ${ }^{45}$ NGOs were also active in promoting stricter tobacco control regulations through lobbying of parliament and use of the court system. ${ }^{46}$ Importantly, these groups' political and legal mobilization occurred across the full range of socio-economic right issues, encompassing education, health, food, work, and social security. ${ }^{47}$

The transformative potential of such changes was severely constrained, however, by broad continuity in the structure of power and interest. While democratization served to empower the poor and NGOs, it did not ultimately undermine the political dominance of the predatory military, bureaucratic and corporate elements and controllers of mobile capital that ruled the New Order. The 
former were able to maintain instrumental control over the state apparatus despite the transition to a more democratic and decentralised political system by forging new alliances and making use of political parties while the economic crisis enhanced the structural power of the latter, especially for the period of the Asian crisis and its immediate aftermath. ${ }^{48}$ This constrained the scope for change because both groups have had only modest interest in the fulfilment of citizens' socio-economic rights.

Controllers of mobile capital — and, in particular, the technocratic government officials who have promoted their agenda within government-have only supported the realization of socioeconomic rights to the extent that it serves to build the country's human resources, creates a stable political and social environment, is affordable, and, in so doing, contributes to economic growth. ${ }^{49}$ In this connection, they have accepted the need for some public investment in education, especially basic education, health and food security programmes - all of which were seen as having some payoff in terms of human capital and political and social stability — but have been opposed to other types of social investment. ${ }^{50}$ Predatory elements have shared this interest, reflecting the fact that they have a significant stake in the country's corporate sector. ${ }^{51}$ At the same time, they have had an interest in limiting government social investments to free up resources for other areas of public spending (e.g. infrastructure, industrial projects, subsidized credit programmes) more central to their business activities ${ }^{52}$ and to the extent that the government has had to spend money on social programmes, a further interest in ensuring that it does so on programs that privilege military and bureaucratic officials - e.g. by providing them with pensions and other benefits, opportunities for corruption, or opportunities to fuel patronage networks and buy electoral votes.

Within this context, citizen and NGO demands for improved protection of socio-economic rights in the post-New Order period became accommodated in government policy and its implementation in a way that fit broadly with the interests of predatory elements and mobile capital controllers. This can be seen most clearly in the extent and pattern of social protection reform since the Asian crisis. First, as the Asian Development Bank (ADB) has observed, Indonesia has spent a 
relatively modest level of resources on social protection compared to other countries in the AsiaPacific. ${ }^{53}$ In 2009, for instance, it spent less on special protection as a share of GDP than all but five Asia-Pacific countries-Papua New Guinea, Cambodia, Vanuatu, Lao PDR, and Nauru-and considerably less than the average for the region's middle income countries. Second, government social protection measures have typically focused on programs in the education, health, and food sectors, not employment or social security. As Tables Two and Three show, this was clearly the case at the national level. Importantly, the enactment of the 2011 Law on Social Security Agencies produced fairly modest change in the extent of social security afforded to Indonesian citizens: while it provided a legal foundation for the national government's health insurance program targeting the poor and created a mechanism by which informal sector workers could self-fund health insurance coverage and pensions, it stopped short of providing for social pensions, unemployment or significant disability benefits. As during the New Order period, civil servants and military officials continued to benefit from their own dedicated and relatively generous pension and health insurance schemes.

\section{INSERT TABLES TWO AND THREE HERE}

Finally, predation and corruption have continued to undermine the implementation of major social protection programs. For instance, there has been public concern about the charging of illegal fees for health and education services and misuse of funds for related social protection schemes such as School Operational Assistance (BOS) and Community Health Insurance (Jamkesmas). Numerous reports have also pointed to corruption in the rice subsidy scheme, Raskin — in particular, incidences of high quality rice being swapped for lower quality rice, rice being sold at higher prices than those set by government with profits being kept by local officials, and/or subsidised rice being sold to the non-poor. ${ }^{54}$ The National Program for Community Empowerment (PNPM) and BLSM, 
an unconditional cash transfer program, have also faced allegations of misused funds and embezzlement (Jakarta Post, July 12, 2011 and April 01, 2014). ${ }^{55}$

\section{Conclusion/Implications}

This paper has sought to shed some light on the political and social conditions under which JLFPHR facilitate the fulfilment of socio-economic rights in developing countries by examining Indonesia's experience vis-à-vis the realization of socio-economic rights since the fall of the New Order regime in the late 1990s. It has argued that democratization contributed to the fulfilment of socio-economic rights by opening up spaces for citizens and rights activists to demand better protection of socio-economic rights and creating an electoral incentive for political leaders to introduce policies aimed at helping the poor fulfill these rights. But the precise way in which these dynamics translated into pro-poor social policy and its implementation was mediated by the continued political dominance of predatory elements and controllers of mobile capital. Specifically, the continued political dominance of these groups ensured that the government's new social protection programmes were modestly funded, focused on areas such as education and health that contribute to capitalist growth, and subject to capture by predatory networks. In other words, it shaped the extent and pattern of socio-economic rights fulfilment. In theoretical terms, then, our analysis suggests that we need to look beyond the role of institutions in shaping the impact of JLFPHR on socio-economic rights outcomes to the way in which institutional and structural factors interact within particular contexts. The point is that, as socially-embedded phenomena, the effects of institutional arrangements are not universal and pre-determined but reflective of particular structures of power and interest that exist at the national level. ${ }^{56}$

What does this mean for efforts to promote the realization of socio-economic rights in developing countries? Scholars employing institutionalist perspectives generally see JLFPHR as having the potential to make a significant contribution to the realization of socio-economic rights. Simmons, for instance, argues that international law is 'a concrete tool' that rights advocates can 
use to achieve their goals. ${ }^{57}$ But recognizing that rights-in-law are not 'self-activating', they have also recommended measures that enable citizens to engage in legal and political mobilization and open up spaces giving them access to state decision making processes. This includes the adoption of democratic reforms and measures to enhance citizens' access to courts either by enhancing their access to support structures for legal mobilization or designing courts so they are easily accessible to the poor without access to these support structures. ${ }^{58}$

Structuralists, by contrast, tend to be more skeptical about the extent to which JLFPHR will contribute to the fulfilment of socio-economic rights even in democratic contexts where citizens are able to mobilise for political and legal action. Given the constraining effects of capitalism, particularly in its neoliberal form, they suggest, JLFPHR are unlikely to yield significant change in the fulfilment of socio-economic rights in the absence of fundamental change in the structure of power and interest. As Cousins puts it: 'Rights are important, but realizing them in practice involves transforming social, political and economic realities.... ${ }^{59}$ In this context, some have called for a shift away from rights-based approaches toward broader programs of political and social struggle aimed at challenging inequalities of wealth and power that impede rights fulfilment. ${ }^{60}$

The analysis here suggests a more nuanced approach. First, it suggests a need for proponents of socio-economic rights to i) differentiate more clearly between structural contexts in which change is likely and those in which it is unlikely ${ }^{61}$ and ii) then invest their time and effort in these contexts. Second, it suggests that proponents of socio-economic rights should recognize that socioeconomic rights are not all of a piece in terms of the political feasibility of their realization within specific contexts. For each context, they need to disaggregate socio-economic rights in recognition of each right's different politics, devising separate strategies for each and, where the prospects of change look poor, desisting from significant effort to promote change in favour of more promising options. The analysis here supports institutionalist recommendations for institutional reforms that enable citizens to engage in legal and political mobilization and open up spaces giving them access to state decision-making processes but with the important caveat that, given rights advocates' 
significant resource and time constraints, efforts to promote mobilization and access ought to focus on contexts where the chances of success are relatively high. While activism is necessary to promote change, it needs to be well directed in order to ensure maximum impact.

\section{Bibliography}

Adioetomo, Sri Moertiningsih, Fiona Howell, Andrea McPherson, and Jan Priebe, Social Assistance for the Elderly in Indonesia: An Empirical Assessment of the ASLUT Programme. TNP2K Working Paper 5. Jakarta: TNP2K, 2013.

Amnesty International. Realizing Sexual and Reproductive Rights: A Human Rights Framework, London: Amnesty International, 2012.

Asian Development Bank. Indonesia: Social Protection Sector Development Program. Manila: Asian Development Bank, 2006.

Asian Development Bank. The Social Protection Index: Assessing Results for Asia and the Pacific. Manila: Asian Development Bank, 2013.

Aspinall, Edward. "Health Care and Democratization in Indonesia." Democratization (2014): 1-21. doi: 10.1080/13510347.2013.873791

Baswir, Revrisond. Pembangunan Tanpa Perasaan : Evaluasi Pemenuhan Hak Ekonomi, Sosial, Budaya Orde Baru. [Development Without Heart: The Evaluation of Economic, Social, and Cultural Rights Fulfilment during the New Order], Yogyakarta: Pustaka Pelajar, IDEA and ELSAM, 1999.

Baxi, Upendra. "Taking Suffering Seriously: Social Action Litigation in the Supreme Court of India." Third World Legal Studies 4, no.4 (1985): 107-32.

Becker, Margaret. "Constructing SSLM: Insights from Struggles over Women's Rights in Nepal." Asian Studies Review 39, no. 2 (2015): 247-65. doi:10.1080/10357823.2015.1021754

Boediono. Ekonomi Indonesia Mau Ke Mana? Kumpulan Esai Ekonomi [Where Is the Economy of Indonesia Going? A Collection of Economic Essays]. Jakarta: Gramedia and Freedom Institute, 2009.

Chang, Mae Chu, Samer Al-Samarrai, Andrew Ragatz, Sheldon Shaeffer, Joppe De Ree, and Ritchie Stevenson. Teacher Reform in Indonesia: The Role of Politics and Evidence in Policy Making. Washington DC: World Bank, 2014.

Cousins, Ben. "Capitalism Obscured: The Limits of Law and Rights-Based Approaches to Poverty Reduction and Development." The Journal of Peasant Studies 36, no. 4 (2009): 893-908. doi: 10.1080/03066150903354098 
Datta, Ajoy, Harry Jones, Vita Febriany, Dan Harris, Rika Kumala Dewi, Leni Wild, and John Young. The Political Economy of Policy-Making in Indonesia. Working Paper 340. London: ODI, 2011.

Dellepiane-Avellaneda, Sebastian. "Review Article: Good Governance, Institutions and Economic Development: Beyond the Conventional Wisdom." British Journal of Political Science 40, no. 1 (2010): 195-224. doi: 10.1017/S0007123409990287

ELSAM. Atas Nama Pembangunan: Bank Dunia Dan Hak Asasi Manusia Di Indonesia [In the name of Development: The World Bank and Human Rights in Indonesia]. Jakarta: ELSAM, 1995.

Epp, Charles. The Rights Revolution: Lawyers, Activists, and Supreme Courts in Comparative Perspective. Chicago: University of Chicago Press, 1998.

Fukuda-Parr, Sakiko, Terra Lawson-Remer, and Susan Randolph. "The International SERF Index Dataset Version 2013". Accessed October 3, 2014. http://www.serfindex.org/data/

Fukuda-Parr, Sakiko, Terra Lawson-Remer, and Susan Randolph. Fulfilling Social and Economic Rights. Oxford: Oxford University Press, 2015.

Fukuoka, Yuki. "Debating Indonesia's Reformasi: Bridging "Parallel Universes",", Journal of Contemporary Asia 44, no. 3 (2014): 540-552. doi:10.1080/00472336.2014.895026

Gauri, Varun. "Social Rights and Economics: Claims to Health Care and Education in Developing Countries." World Development 32, no. 3 (2004): 465-77. $\quad$ doi: 10.1016/j.worlddev.2003.07.009

Ginsburg, Tom. Judicial Review in New Democracies: Constitutional Courts in Asian Cases. Cambridge: Cambridge University Press, 2003.

Government of Indonesia. Report on the Achievement of the Millennium Development Goals in Indonesia 2011. Jakarta: Bappenas, 2011.

Grenfell, Laura. "Realising Rights in Timor-Leste." Asian Studies Review 39, no. 2 (2015): 266-83. doi: 10.1080/10357823.2015.1023770

Grugel, Jean, and Enrique Peruzzotti. "The Domestic Politics of International Human Rights Law: Implementing the Convention on the Rights of the Child in Ecuador, Chile, and Argentina." Human Rights Quarterly 34, no. 1 (2012): 178-98. doi: 10.1353/hrq.2012.0013

Grugel, Jean, and Nicola Piper. Critical Perspectives on Global Governance: Rights and Regulation in Governing Regimes. London and New York: Routledge, 2007.

Grugel, Jean, and Nicola Piper. "Do Rights Promote Development?" Global Social Policy 9, no. 1 (2009): 79-98. doi: 10.1177/1468018108100399

Hadiz, Vedi. "Reorganizing Political Power in Indonesia: A Reconsideration of So-Called 'Democratic Transitions'." The Pacific Review 16, no. 4 (2003): 591-611. DOI:10.1080/0951274032000132272 
Harriss, John. Power Matters: Essays on Institutions, Politics, and Society in India. New Delhi: Oxford University Press, 2006.

Hickey, Samuel, Kunal Sen and Badru Bukenya "Exploring the Politics of Inclusive Development: Towards a New Conceptual Approach" in The Politics of Inclusive Development: Interrogating the Evidence, edited by Samuel Hickey, Kunal Sen and Badru Bukenya, 3-34. Oxford: Oxford University Press, 2015.

Hoemardani, Soedjono. Renungan Tentang Pembangunan [Thoughts about Development]. Jakarta: Center for Strategic and International Studies, 1975.

International Labour Organization. "Overview of Schemes". 2013. Accessed October 8, 2014. http://www.ilo.org/dyn/ilossi/ssimain.schemes?p_lang=enandp_geoaid=360

Joshi, Anuradha. "Do Rights Work? Law, Activism, and the Employment Guarantee Scheme." World Development 38, no. 4 (2010): 620-30. doi:10.1016/j.worlddev.2009.11.012

Joshi, Anuradha, and Mick Moore. "Enabling Environments: Do Anti-Poverty Programmes Mobilise the Poor?" Journal of Development Studies 37, no. 1 (2000): 25-56. doi: $10.1080 / 713600057$

Khan, Irene. The Unheard Truth: Poverty and Human Rights, New York: W.W. Norton and Company (2009).

Leys, Colin. "Capital Accumulation, Class Formation and Dependency-the Significance of the Kenyan Case." Socialist Register 15 (1978): 241-66.

Lindsey, Tim. "Indonesian Constitutional Reform: Muddling Towards Democracy." In Indonesia: Law and Society, edited by Tim Lindsey, 23-47. Sydney: The Federation Press, 2008.

Mahkamah Agung. "Putusan Nomor 05 P/Hum/Th.2005 [Decision Number 05 P/Hum/Th.2005]." Jakarta: Mahkamah Agung, 2006.

McCann, Michael. Rights at Work: Pay Equity Reform and the Politics of Legal Mobilization. Chicago: University of Chicago Press, 1994.

Mietzner, Marcus. Indonesia's 2009 Elections: Populism, Dynasties and the Consolidation of the Party System. Sydney: Lowy Institute for International Policy (2009).

Ministry of Social Affairs. "Policy Report: Sinergi Dalam Program Asodkb [Policy Report: Synergies in the Asodkb Program]." Accessed September 18, 2014. https://www.kemsos.go.id/unduh/Roren/rpjmd-laporan/asodkb-naskah-kebijakan-rorenkemsos-2013.pdf

Mitlin, Diana, and Samuel Hickey, Rights-Based Approaches to Development: Exploring the Potential and Pitfalls. Sterling: Kumarian Press, 2009.

Moertopo, Ali. Strategi Pembangunan Nasional [Strategy for National Development]. Jakarta: Center for Strategic and International Studies, 1981. 
North, Douglass. Structure and Change in Economic History. New York: Norton, 1981.

North, Douglass. "Economic Performance through Time." American Economic Review 84, no. 3 (1994): 359-68.

Piper, Nicola. "The "Migration-Development Nexus" Revisited from a Rights Perspective." Journal of Human Rights 7, no. 3 (2008): 282-298. doi: 10.1080/14754830802285964.

Pratisto, Sujud Dwi "Memburu Tambang Emas Biru [Pursuing the Blue Gold Mine]" Gatra 2006: 68-69.

Prawiro, Radius. Indonesia's Struggle for Economic Development: Pragmatism in Action. Oxford University Press. Oxford 1998.

Pritchett, Lant, Asep Suryahadi, and Sudarno Sumarto. Targeted Programs in an Economic Crisis: Empirical Findings from the Experience of Indonesia. Jakarta: SMERU, 2002.

Riady, John. 2013. "Jokonomics, Social Welfare and the Future of Indonesia " Jakarta Globe, 11 April. http://thejakartaglobe.beritasatu.com/opinion/jokonomics-social-welfare-and-thefuture-of-indonesia/

Rodan, Garry, Kevin Hewison, and Richard Robison. The Political Economy of South-East Asia: Markets, Power and Contestation. Melbourne: Oxford Press, 2006.

Rodan, Garry, and Kanishka Jayasuriya. "Hybrid Regimes: A Social Foundations Approach." in Routledge Handbook of Democratization. Edited by Jeffrey Haynes, 175-89. London: Routledge, 2012.

Rosenberg, Gerald. The Hollow Hope: Can Courts Bring About Social Change? Chicago: University of Chicago Press, 1991.

Rosser, Andrew. "Contesting Tobacco-Control Policy in Indonesia." Critical Asian Studies 47, no. 1 (2015): 69-93. doi:10.1080/14672715.2015.997083

Rosser, Andrew. "Law and the Realisation of Human Rights: Insights from Indonesia's Education Sector." Asian Studies Review 39, no. 2 (2015): 194-212. doi:10.1080/14672715.2015.997083

Rosser, Andrew "Resisting Marketisation: Everyday Actors, Courts and Education Reform in PostNew Order Indonesia." The Everyday Political Economy of Southeast Asia. Edited by Juanita Elias and Lena Rethel. Cambridge University Press: Cambridge, (forthcoming).

Sangmpam, S.N. "Politics Rules: The False Primacy of Institutions in Developing Countries." Political Studies 55, no. 1 (2007): 201-24. Doi: 10.1111/j.1467-9248.2007.00650.x

Satriana, Sinta, Valerie Schmitt, and Muhamad Tauvik. Social Protection Assessment Based National Dialogue: Towards a Nationally Defined Social Protection Floor in Indonesia. Jakarta: International Labour Organization, 2012. 
Scheingold, Stuart. The Politics of Rights: Lawyers, Public Policy, and Political Change. 2nd ed. Ann Arbor: University of Michigan Press, 1974.

Simmons, Beth. Mobilizing for Human Rights: International Law in Domestic Politics. Cambridge: Cambridge University Press, 2009.

SMERU. Rice for Poor Families (Raskin): Did the 2002 Program Operate Effectively? Evidence from Bengkulu and Karawang. Jakarta: SMERU Research Institute, 2003.

SMERU. The Effectiveness of the Raskin Program Jakarta. Jakarta: SMERU Research Institute, 2008.

Sumarto, Mulyadi. Perlindungan Sosial Dan Klientelisme: Makna Politik Bantuan Tunai Dalam Pemilihan Umum [Social Protection and Clientelism: The Political Purpose of Cash Transfers in General Elections]. Yogyakarta: Gadjah Mada University Press, 2014.

Sumarto, Sudarno, and Samuel Bazzi, "Social Protection in Indonesia: Past Experiences and Lessons for the Future". Paper presented at the Annual Bank Conference on Development Opportunities (ABCDE) jointly organised by the World Bank and OECD. Paris, 30 May-1 June, 2011.

Tjandra, Surya. The Indonesian Trade Union Movement under Reformasi. mimeo, 2014.

Widjaja, Muliadi. "Indonesia: In Search of a Placement-Support Social Protection." ASEAN Economic Bulletin 29, no. 3 (2012): 184-96. doi: 10.1355/ae29-3b

Wilson, Bruce. "Institutional Reform and Rights Revolutions in Latin America: The Cases of Costa Rica and Colombia." Journal of Politics in Latin America 1, no. 2 (2009): 59-85.

Wilson, Bruce "Health Rights Litigation: Causes and Consequences." In Litigating Health Rights: Can Courts Bring More Justice to Health? Edited by Alicia Yamin and Siri Gloppen. Cambridge, 132-154. MA: Harvard University Press, 2011. 


\section{Table One}

The Fulfilment of Socio-economic Rights in Indonesia

\begin{tabular}{|l|r|r|r|}
\hline & 1995 & 2005 & 2012 \\
\hline SERF Core Countries Index & 55.66 & 70.67 & 65.71 \\
\hline Component Indices: & & & \\
\hline SERF Right to Health Index & 78.75 & 84.97 & 85.16 \\
\hline SERF Right to Education Index & 71.69 & 79.29 & 93.43 \\
\hline SERF Right to Food Index & 45.16 & 74.79 & 45.01 \\
\hline SERF Right to Housing Index & 58.52 & 66.29 & 63.88 \\
\hline SERF Right to Work Index & 24.2 & 48.03 & 41.09 \\
\hline
\end{tabular}

Source: Fukuda-Parr, Lawson-Remer, and Randolph, Fulfilling Social and Economic Rights. 
Table Two

Major Post-Crisis Social Protection Programmes

\begin{tabular}{|c|c|c|c|}
\hline Programme Name & Sector & Programme Description & Intended coverage \\
\hline \multicolumn{4}{|l|}{$\begin{array}{l}\text { First Generation (1998- } \\
2000)\end{array}$} \\
\hline Rice subsidy (OPK) & Food security & The sale of subsidized rice to the poor & 12.8 million \\
\hline $\begin{array}{l}\text { Employment creation } \\
\text { (Padat Karya) }\end{array}$ & Employment & $\begin{array}{l}\text { Labour programmes in a variety of } \\
\text { government departments }\end{array}$ & 12.7 million days \\
\hline $\begin{array}{l}\text { Scholarships and block } \\
\text { grants to schools (SBG) }\end{array}$ & Education & $\begin{array}{l}\text { Scholarships for elementary, lower } \\
\text { secondary, and upper secondary } \\
\text { students and block grants to selected } \\
\text { schools }\end{array}$ & $\begin{array}{l}6 \% \text { of primary, } 17 \% \text { of } \\
\text { lower secondary, } 10 \% \text { of } \\
\text { upper secondary school } \\
\text { students }\end{array}$ \\
\hline Health cards (SSN-BK) & Health & Subsidies for medical services & 7.4 million households \\
\hline $\begin{array}{l}\text { Community } \\
\text { empowerment (PDM- } \\
\text { DKE) }\end{array}$ & $\begin{array}{l}\text { Community } \\
\text { development }\end{array}$ & $\begin{array}{l}\text { Block grants for villages for public } \\
\text { works or revolving funds for credit }\end{array}$ & $\begin{array}{l}\text { Almost all villages in the } \\
\text { country }\end{array}$ \\
\hline Programme Name & Sector & Programme Description & Current Coverage* \\
\hline \multicolumn{4}{|l|}{$\begin{array}{l}\text { Second Generation (2000 } \\
\text { onward) }\end{array}$} \\
\hline Rice Subsidy (Raskin) & Food security & Rice subsidy for the poor & 17.5 Million households \\
\hline $\begin{array}{l}\text { Health Card } \\
\text { (Jamkesmas) }\end{array}$ & Health. & $\begin{array}{l}\text { Free health insurance for the poor. } \\
\text { Previously Askeskin }\end{array}$ & 76.4 million poor people \\
\hline $\begin{array}{l}\text { Scholarships (SSM \& } \\
\text { BSM) }\end{array}$ & Education & $\begin{array}{l}\text { Scholarships for poor students from } \\
\text { both public and private schools. }\end{array}$ & 6.3 million students \\
\hline $\begin{array}{l}\text { Family Hope Program } \\
\text { (PKH) }\end{array}$ & Safety net & $\begin{array}{l}\text { Conditional cash transfer. Cash on the } \\
\text { condition that health and education } \\
\text { conditions are met. }\end{array}$ & 1.5 million households \\
\hline $\begin{array}{l}\text { School operational } \\
\text { subsidy (BOS) }\end{array}$ & Education & $\begin{array}{l}\text { Provides } 9 \text { years free basic education } \\
\text { to all students. }\end{array}$ & 44.7 million students \\
\hline $\begin{array}{l}\text { National program for } \\
\text { community } \\
\text { empowerment (PNPM) }\end{array}$ & $\begin{array}{l}\text { Community } \\
\text { development. }\end{array}$ & $\begin{array}{l}\text { Program targets poor or rural areas } \\
\text { providing block grants for community } \\
\text { development projects. }\end{array}$ & 6,622 sub-districts \\
\hline $\begin{array}{l}\text { Temporary direct cash } \\
\text { transfer for fuel (BLSM) }\end{array}$ & Safety net & $\begin{array}{l}\text { A temporary unconditional cash } \\
\text { transfer program to help the poor cope } \\
\text { with the rising price of fuel }\end{array}$ & $\begin{array}{l}18 \text { million households } \\
\text { (2008) }\end{array}$ \\
\hline $\begin{array}{l}\text { Informal workers } \\
\text { Insurance (Askesos) }\end{array}$ & Insurance & $\begin{array}{l}\text { An income replacement scheme for } \\
\text { informal workers. }\end{array}$ & 359,000 members (2011) \\
\hline $\begin{array}{l}\text { Health insurance (PT } \\
\text { Jamsostek) }\end{array}$ & Health & $\begin{array}{l}\text { Healthcare benefits (healthcare, work } \\
\text { injury, death, and old age benefits) for } \\
\text { formal sector }\end{array}$ & $\begin{array}{l}5,884,528 \text { beneficiaries } \\
(2011)\end{array}$ \\
\hline $\begin{array}{l}\text { Health Insurance (PT } \\
\text { Askes) }\end{array}$ & Health & $\begin{array}{l}\text { Health insurance for private sector } \\
\text { (armed forces, civil servants retired } \\
\text { military veterans). }\end{array}$ & $16,482,331$ people $(2010)$ \\
\hline Pension (PT Taspen) & Pension & $\begin{array}{l}\text { Government Civilian Employees } \\
\text { Saving and Insurance Scheme. } \\
\text { Pension and old age saving for civil } \\
\text { servants. }\end{array}$ & $\begin{array}{l}2,361,408 \text { pensioners } \\
\text { receiving pension and } \\
4,598,100 \text { active civil } \\
\text { servants making } \\
\text { contributions }(2011)\end{array}$ \\
\hline Pension (PT Asabri) & Pension & $\begin{array}{l}\text { Armed Forces Social Insurance Plan. } \\
\text { Pension and old age savings for } \\
\text { military and armed forces. }\end{array}$ & $1,159,715$ members $(2010)$ \\
\hline $\begin{array}{l}\text { Universal delivery care } \\
\text { (Jampersal) }\end{array}$ & Health & $\begin{array}{l}\text { Universal delivery care, provides } \\
\text { women with free birth delivery, pre- } \\
\text { natal and post-natal check-ups. }\end{array}$ & $\begin{array}{l}2.6 \text { million deliveries }(60 \\
\text { per cent of estimated } 4.8 \\
\text { million total deliveries) } \\
(2011)\end{array}$ \\
\hline
\end{tabular}




\begin{tabular}{|l|l|l|l|}
\hline $\begin{array}{l}\text { Elderly social protection } \\
\text { (ASLUT) }\end{array}$ & Pension & $\begin{array}{l}\text { Cash transfer assistance for vulnerable } \\
\text { elderly. }\end{array}$ & 26.500 beneficiaries (2013) \\
\hline $\begin{array}{l}\text { Social assistance for } \\
\text { severely disabled' } \\
\text { (ASODKB) }\end{array}$ & Safety net & $\begin{array}{l}\text { Cash transfer for people with severe } \\
\text { disabilities. }\end{array}$ & $\begin{array}{l}19,500 \text { disabled people } \\
(2011)\end{array}$ \\
\hline $\begin{array}{l}\text { Social Welfare } \\
\text { Institution for Children } \\
\text { program (PKSA) }\end{array}$ & Safety net & $\begin{array}{l}\text { Provision of cash transfer for } \\
\text { marginalized children in need. }\end{array}$ & 156,335 children (2011) \\
\hline
\end{tabular}

*data from 2012 unless stated otherwise.

Sources: Datta et al., The Political Economy of Policy-Making in Indonesia; International Labour Organization, "Overview of Schemes." Pritchett, Suryahadi, and Sumarto. Targeted Programs in an Economic Crisis; Satriana, Valerie, and Tauvik, Social Protection Assessment Based National Dialogue; Sumarto and Bazzi, "Social Protection in Indonesia."; and Widjaja, "Indonesia: In Search of a Placement-Support Social Protection." 
Table Three

Social Protection Programme Budgets, 2012

\begin{tabular}{lc}
\hline \multicolumn{1}{c}{ Programme } & Budget (IDR) \\
\hline School Operational Assistance (BOS) & 23.6 trillion \\
Temporary Direct Cash Assistance (BLSM) & 17 trillion \\
Rice for the Poor (Raskin) & 15.7 trillion \\
Community Empowerment Program (PNPM) & 13.4 trillion \\
Community Health Protection (Jamkesmas) & 7.3 trillion \\
Scholarship for Poor Students (BSM) \& Subsidies for & 5.9 trillion \\
Poor Students (SSM) & 1.8 trillion \\
Family Hope Program (PKH) & 79.2 billion \\
Assistance for the Severely Disabled (ASODKB) & 63.6 billion \\
\hline Assistance for the Neglected Elderly (ASLUT) & \\
\hline
\end{tabular}

Sources: Satriana, Valerie, and Tauvik, Social Protection Assessment Based National Dialogue; Adioetomo, Howell, McPherson, and Priebe, Social Assistance for the Elderly in Indonesia; Jakarta Post, March 28, 2012; and Ministry of Social Affairs, "Policy Report: Sinergi Dalam Program Asodkb."

\section{Endnotes}

\footnotetext{
${ }^{1}$ Fukuda-Parr, Lawson-Remer, and Randolph, Fulfilling Social and Economic Rights, 4.

${ }^{2}$ Gauri, "Social Rights and Economics," 465.

${ }^{3}$ Mitlin and Hickey, Rights-Based Approaches to Development, 3.

${ }^{4}$ Fukuda-Parr, Lawson-Remer, and Randolph, Fulfilling Social and Economic Rights, 102-103.
}

5 The SERF Index measures the extent to which countries are meeting their obligations to fulfill five rights provided for in the ICESCR: the right to food, the right to housing, the right to health care, the right to education, and the right to decent work. Fulfillment of these rights is measured by: in the case of food, the percentage of children under 5 who are not stunted; in the case of education, primary school completion rates and combined gross school enrolment rates; in the case of health, the child mortality rate, the age 65 survival rate, and the contraception use rate; in the case of housing, the proportion of the rural population with access to an improved water source and the proportion of the population with access to improved sanitation; and in the case of work, the percentage of the population that earns more than $\$ 2$ per day. The five rights are equally weighted as are the indicators within each right. The right to social security is excluded from the index on the grounds that there are no reliable available measures. See Fukuda-Parr, LawsonRemer, and Randolph, Fulfilling Social and Economic Rights for a more detailed description of the composition of the index.

${ }^{6}$ Ibid., 110.

${ }^{7}$ Khan, The Unheard Truth, 203.

${ }^{8}$ See, for instance, the recommendations made in Amnesty International, Realizing Sexual and Reproductive Rights..

9 Epp, The Rights Revolution; Simmons, Mobilizing for Human Rights; Cousins, "Capitalism Obscured."; Wilson, "Institutional Reform and Rights Revolutions in Latin America."; Wilson, "Health Rights Litigation."; and Joshi, "Do Rights Work?"

${ }^{10}$ See, for instance, Simmons, Mobilizing for Human Rights and Fukuda-Parr, Lawson-Remer, and Randolph, Fulfilling Social and Economic Rights.

${ }^{11}$ See, for instance, Cousins, "Capitalism Obscured."

12 See Sangmpam, "Politics Rules." and Dellepiane-Avellaneda, "Review Article: Good Governance, Institutions and Economic Development." for surveys of this literature.

${ }^{13}$ North, Structure and Change in Economic History. and North, "Economic Performance through Time."

${ }^{14}$ Fukuda-Parr, Lawson-Remer, and Randolph, Fulfilling Social and Economic Rights, 132-133. 
15 Ibid., 129.

16 Joshi and Moore. "Enabling Environments."

${ }^{17}$ Simmons, Mobilizing for Human Rights.

18 Ibid.

${ }^{19}$ Ibid., 16.

${ }^{20}$ Epp, The Rights Revolution.

21 Becker, "Constructing SSLM." and Grenfell, "Realising Rights in Timor-Leste."

${ }^{22}$ Wilson, "Institutional Reform and Rights Revolutions in Latin America." and Wilson, "Health Rights Litigation."

23 Ginsburg, Judicial Review in New Democracies.

24 Leys, "Capital Accumulation, Class Formation and Dependency-the Significance of the Kenyan Case."; Rodan, Hewison, and Robison, The Political Economy of South-East Asia; Harriss, Power Matters; and Rodan and Jayasuriya, "Hybrid Regimes."

25 Scheingold, The Politics of Rights; Rosenberg, The Hollow Hope; and McCann, Rights at Work.

${ }^{26}$ Cousins, "Capitalism Obscured."

27 Baxi, "Taking Suffering Seriously."

28 Ibid., 132.

29 Grugel and Piper, Critical Perspectives on Global Governance. and Grugel and Piper, "Do Rights Promote Development?"

30 Grugel and Piper, "Do Rights Promote Development?" 94.

31 Grugel and Peruzzotti, "The Domestic Politics of International Human Rights Law."

32 Piper, "The "Migration-Development Nexus"."

33 Rosser, "Law and the Realisation of Human Rights."

34 Lindsey, "Indonesian Constitutional Reform," 29.

35 Fukuda-Parr, Lawson-Remer, and Randolph, Fulfilling Social and Economic Rights, 104.

36 Countries with similar scores included Lao PDR, Cambodia, Bangladesh, Uganda, Ethiopia, Central African Republic, and Mozambique.

37 The SERF Right to Food index probably underestimates the country's progress in terms of realizing the right to food. The Index is built on a single indicator - the proportion of children under five who are not stunted-that, in the Indonesian context at least, appears to be subject to some fluctuation probably due to changes to measurement methodology. Other relevant indicators such as the prevalence of underweight children under 5 years old and the proportion of the population below a minimum level of dietary energy consumption have shown more substantial and secular improvement during the same period, suggesting that the country's performance vis-à-vis the right to food is in fact somewhat better than the SERF index data suggest (See Government of Indonesia. Report on the Achievement of the Millennium Development Goals in Indonesia 2011).

${ }^{38}$ Ibid.

${ }^{39}$ Mietzner, Indonesia's 2009 Elections and Aspinall, "Health Care and Democratization in Indonesia."

${ }^{40}$ On this, see Chang et al., Teacher Reform in Indonesia.

41 Rosser, "Contesting Tobacco-Control Policy in Indonesia."; Rosser, "Law and the Realisation of Human Rights."; and Rosser, "Resisting Marketisation.".

42 See, for instance, ELSAM, Atas Nama Pembangunan and Baswir, Pembangunan Tanpa Perasaan.

43 Mietzner, Indonesia's 2009 Elections.

44 Pratisto, "Memburu Tambang Emas Biru."; Mahkamah Agung. "Putusan Nomor 05 P/Hum/Th.2005."; Rosser, "Law and the Realisation of Human Rights."; and Rosser, "Resisting Marketisation.".

45 Tjandra, "The Indonesian Trade Union Movement under Reformasi."

46 Rosser, "Contesting Tobacco-Control Policy in Indonesia."

47 Rosser, "Contesting Tobacco-Control Policy in Indonesia." and Rosser, "Law and the Realisation of Human Rights."

${ }^{48}$ Hadiz, "Reorganizing Political Power in Indonesia.”, 593; See Fukuoka, "Debating Indonesia's Reformasi." for a review of the literature on Indonesia's post-New Order transition.

${ }^{49}$ Prawiro, Indonesia's Struggle for Economic Development, 173-211, 130-134; Asian Development Bank. Indonesia: Social Protection Sector Development Program; and Boediono, Ekonomi Indonesia Mau Ke Mana?, 13,31.

50 Prawiro, Indonesia's Struggle for Economic Development, 173-211, 130-134.

51 Hoemardani, Renungan Tentang Pembangunan and Moertopo, Strategi Pembangunan Nasional.

52 Riady, "Jokonomics, Social Welfare and the Future of Indonesia."

53 Asian Development Bank. The Social Protection Index, 13-14. 
54 SMERU, Rice for Poor Families (Raskin), 26, 40 and SMERU, The Effectiveness of the Raskin Program Jakarta, 910 .

55 Sumarto, Perlindungan Sosial Dan Klientelisme.

56 Rodan and Jayasuriya, "Hybrid Regimes."

57 Simmons, Mobilizing for Human Rights, 377.

58 See, for instance, Epp, The Rights Revolution; Simmons, Mobilizing for Human Rights; and Wilson, "Institutional Reform and Rights Revolutions in Latin America.".

59 Cousins, "Capitalism Obscured," 906.

${ }^{60}$ Cousins, "Capitalism Obscured." and Grugel and Piper, "Do Rights Promote Development?"

${ }^{61}$ In this respect, our analysis has much in common with recent work on 'the politics of inclusive development' (See Hickey, Sen and Bukenya "Exploring the Politics of Inclusive Development."). This work has demonstrated that the nature of 'political settlements' varies from country to country, in turn shaping institutions and how they work. Hence the same institutions can have quite different effects in different contexts depending on the underlying structural context. 


\section{University Library}

\section{- M M I N E R VA A gateway to Melbourne's research publications}

Minerva Access is the Institutional Repository of The University of Melbourne

\section{Author/s:}

Rosser, A; van Diermen, M

Title:

Law, democracy and the fulfilment of socioeconomic rights: insights from Indonesia

Date:

2016-02-01

Citation:

Rosser, A. \& van Diermen, M. (2016). Law, democracy and the fulfilment of socioeconomic rights: insights from Indonesia. THIRD WORLD QUARTERLY, 37 (2), pp.336-353. https:// doi.org/10.1080/01436597.2015.1108829.

Persistent Link:

http://hdl.handle.net/11343/268127 